\title{
Speciation of Chromium in Soil and Sludge in the Surrounding Tannery Region, Ranipet, Tamil Nadu
}

\author{
Badal Kumar Mandal, Raviraj Vankayala, and L. Uday Kumar \\ Trace Elements Speciation Research Laboratory, Environments and Analytical Chemistry Division, School of Advanced Sciences, \\ VIT University, Vellore 632014, India
}

Correspondence should be addressed to Badal Kumar Mandal, mbadal@hotmail.com

Received 22 June 2011; Accepted 26 July 2011

Academic Editors: S. K. Brar and S. M. Waliszewski

Copyright ( $\odot 2011$ Badal Kumar Mandal et al. This is an open access article distributed under the Creative Commons Attribution License, which permits unrestricted use, distribution, and reproduction in any medium, provided the original work is properly cited.

\begin{abstract}
The distribution and mobility of chromium in the soils and sludge surrounding a tannery waste dumping area was investigated to evaluate its vertical and lateral movement of operational speciation which was determined in six steps to fractionate the material in the soil and sludge into (i) water soluble, (ii) exchangeable, (iii) carbonate bound, (iv) reducible, (v) oxidizable, and (vi) residual phases. The present study shows that about $63.7 \%$ of total chromium is mobilisable, and $36.3 \%$ of total chromium is nonbioavailable in soil, whereas about $30.2 \%$ of total chromium is mobilisable, and $69.8 \%$ of total chromium is non-bioavailable in sludge. In contaminated sites the concentration of chromium was found to be higher in the reducible phase in soils (31.3\%) and oxidisable phases in sludge (56.3\%) which act as the scavenger of chromium in polluted soils. These results also indicate that iron and manganese rich soil can hold chromium that will be bioavailable to plants and biota. Thus, results of this study can indicate the status of bioavailable of chromium in this area, using sequential extraction technique. So a suitable and proper management of handling tannery sludge in the said area will be urgently needed to the surrounding environment as well as ecosystems.
\end{abstract}

\section{Introduction}

Chromium $(\mathrm{Cr})$ is the seventh most abundant available element on the Earth and 21st in the Earth's crust, with an average concentration of $100 \mathrm{mg} / \mathrm{kg}$. The maximum concentration of chromium allowed in drinking water is $0.10 \mathrm{mg} / \mathrm{L}$ due to the toxic effects of $\mathrm{Cr}(\mathrm{VI})$ and the potential for oxidation of $\mathrm{Cr}(\mathrm{III})$ to $\mathrm{Cr}(\mathrm{VI})$ [1]. The discharge of $\mathrm{Cr}(\mathrm{VI})$ to surface water is regulated to below $0.05 \mathrm{mg} / \mathrm{L}$ by the US EPA [2]. The presence of an excess amount of chromium beyond the tolerable limits makes the land unsuitable for crop growth [3], and the fertility is also adversely affected by wastewater emanating from tanneries [4]. Although the majority of the researchers consider that $\mathrm{Cr}(\mathrm{VI})$ is removed by anionic adsorption onto the biomaterials [5], basically the removal mechanism of $\mathrm{Cr}(\mathrm{VI})$ by natural biomaterials is adsorption-coupled reduction [6].

As per 2001 census population of the surrounding towns of Ranipet adjacent to Palar river basin that is, Vaniyambadi, Ambur, Pernampattu, and Ranipettai are 103,841; 99,855;
41,$323 ; 36,675$, respectively, with 138 tanneries in Vaniyambadi, 83 tanneries in Ambur, 18 tanneries in Pernampattu, and 39 tanneries in Ranipettai. Due to mushrooming of tanneries day by day the study became imperative to check the flow of chromium and other heavy metals in the region. Although some of the tanning industries have been closed down which neither had their own effluent treatment plants nor were connected to a common effluent treatment facility, this hardly made any difference on the ground as tanneries had been discharging effluents for several decades. A large number of small-scale tanneries located within the country do not have access to a common treatment plant and discharge their wastes in open fields or dump them in landfill sites. The use of sludge as a cheap manure in agricultural practices is also not uncommon in this region. These indiscrete methods of disposal contaminate the soil and water providing an easy pathway of $\mathrm{Cr}$ in the food chain.

Plant uptake of chromium accounted for less than $1 \%$ of the chromium removed from the soil [7]. Once assimilated by plants, $\mathrm{Cr}(\mathrm{VI})$ is readily reduced to $\mathrm{Cr}(\mathrm{III})$ [8]. Overall, 
the addition of organic matter had the strongest influence on chromium mobility [7]. Although bioremediation of $\mathrm{Cr}(\mathrm{VI})$ to $\mathrm{Cr}(\mathrm{III})$ is a viable cleanup approach, it produces soluble organo-Cr(III) complexes in the environment which depends on the organic ligands [9]. Further, microbial degradation is inactive towards these soluble organo- $\mathrm{Cr}$ (III) complexes (citrate-Cr(III) > malate-Cr(III) > histidine$\mathrm{Cr}$ (III) i.e., TCA cycle metabolites). In addition, in mammalian cells the formation of stable DNA-Cr(III) adducts impairs and blocks DNA replication causing mutation [10] which proofs its strong affinity towards organic ligands [11]. Chromate mobility is enhanced in neutral $\mathrm{pH}$ groundwater, especially in the presence of competing oxyanions [12-14]. Furthermore, the movement of chromium is associated with its oxide state; that $\mathrm{Cr}(\mathrm{VI})$ transforms into more stable $\mathrm{Cr}(\mathrm{III})$ is a key progress; organic matter and fertilizers can change the state of heavy metals to reduce its toxicity and promote the removal of chromium [15].

Basic chromium sulfate (BCS) as used in leather tanning processes is not wholly taken up by the hides and skins. Its uptake is limited to $55-70 \%$, and the remaining portion is discharged as waste. Therefore, about $40 \%$ of the $\mathrm{Cr}$ amount remains in the solid and liquid wastes (especially spent tanning solutions) [16, 17]. The presence of $\mathrm{Cr}(\mathrm{III})$ and its salts in the sludge of both the wastewater biological treatment plants or the chemical plants for recycling spent tanning liquors represents an inconvenience for the safe reuse of these sludge and a cost forming factor for their disposal as well as a real threat to environment. Also, tanneries are doing illegal dumping of wastewater and sludge that causes serious environmental pollution.

Tanning is one of the oldest and fastest growing industries in India. There are about 2,000 tanneries located at different centers with a total processing capacity of 600,000 tons of hides and skins per year [18]. Two major sources of $\mathrm{Cr}$ contamination are sludge-treated/amended soil [19] and uncontrolled disposal of wastes [20]. It is estimated that in India alone, about 2000-3000 tones of $\mathrm{Cr}$ escape into environment annually from the tanning industries, with $\mathrm{Cr}$ concentration ranging between 2000 and $5000 \mathrm{mg} / \mathrm{L}$ in the aqueous effluent, compared to the recommended permissible limit of $2 \mathrm{mg} / \mathrm{L}$ while $0.05 \mathrm{mg} / \mathrm{L}$ in drinking water [21]. Hence, in 1995, the Supreme Court of India ordered the closure of hundreds of tanneries in Tamil Nadu for failing to treat their effluents [22]. The Tamil Nadu Pollution Control Board (TNPCB) estimates that about 150,000 tons of solid wastes accumulated over two decades of plant operation were stacked in an open yard (three to five meters high and on 2 hectares of land) on the facility premises.

It is common conception nowadays that the total concentrations of metals in soils are not a good indicator of phytoavailability, or a good tool for potential risk assessment, due to the different and complex distribution patterns of metals among various chemical species or solid phases [17, 23, 24]. Wang et al. [25] reported that correlation was better between plant growth and available $\mathrm{Cr}$ than between plant growth and total Cr. It has long been recognized that the soluble, exchangeable, and loosely adsorbed metals are quite labile and hence more bioavailable for plants [26, 27]. Also, clayey soil might have high sorption capacity for $\mathrm{Cr}$ than other types of soils [28].

Total metal content of soils is useful for many geochemical applications but the speciation (bioavailability) of these metals is more valuable agriculturally because this form of metal will be bioavailable for plant uptake or extractable to groundwater or animal/human consumption [29-33]. Since mineralogy and chemistry of the soil sample determine the phases or forms of metal salts present, the solubility of these metal salts mostly depends on ionic strength or chemical composition of the extractants. Metal can exist in water soluble, carbonate and sulfide bound, reducible (Fe and Mn oxide bound), oxidisable (organic matter bound), and residual (lattice bound) forms in soils and sludge. Data on metal concentration in each phase are urgently important to access its bioavailability and mobility in underground soil strata under different geochemical environments.

No single extractant can leach all forms of metal phases in soil, and hence other chemical speciation techniques [31] are not suitable except Sequential Extraction Procedures (SEP). There are several SEP available in the literature [32-37]. Despite the nonselectivity of the reagents used, handling of sediment prior to extraction, sediment-reagent ratio, and length of extraction lead to dubious data collected from SEP [29] and even ends up with inconsistent results using repeatedly the same SEP, these techniques are unanimously accepted and adopted for speciation of metal bound to different salts in soils and sludge.

There is not enough scientific information about the leaching of $\mathrm{Cr}$ from the dump of tannery sludge as well as bioavailable $\mathrm{Cr}$ to plants and animals in Ranipet region of Vellore district. Therefore, the present study brought an insight into the much needed information on the fate of $\mathrm{Cr}$ on and around the dumping site in the study area using SEP.

The main objectives of the present study were (1) to study the viability of dumping tannery sludge in an open place for a long time; (2) to study the percentage of bioavailable chromium present in the sludge and the effluent; (3) to study the percentage of leachable chromium present in the sludge and effluent contaminating ground water; (4) to study the percentage of immobilisable chromium present in the sludge and effluent for long run.

\section{Materials and Methods}

2.1. Reagents. All chemicals were of analytical grades. Potassium dichromate, diphenylcarbazide, cupferron, sulphuric acid, chloroform, nitric acid, and 30\% hydrogen peroxide were purchased from SD Fine Chemicals (Bombay, India) and Qualigens (GlaxoSmithKline, Bombay, India). All samples were prepared using double distilled water.

2.2. Protocol. Samples (sludge, effluent and soils) were collected from in and around Ranipet Common Effluent Treatment Plant area near Walajapet (about 100 miles from Chennai), paddy field and agricultural fields. Sequentially extracted, acid and microwave-digested samples were analyzed by UV-Visible Spectrophotometer (Schimadzu 8500 II, Tokyo, Japan). Standard Colorimetric Method 3500-D of 
American Public Health Association (APHA) for Cr analysis was adopted in the present study [38]. For acid digestion EPA-3050B method was performed, and for microwaveassisted digestion of samples EPA 3052 method was adopted in the present study for soil and sludge samples.

2.3. Sample Collection. The site chosen for the present study was the Ranipet Common Effluent Treatment Plant (RCETP) area near Walajapet. Tannery is the basic unit of leather industry, which requires large amount of water and chemicals and major parts of it are discharged as effluent. There are more than 200 Tanneries and finished leather goods manufacture industries located in the above specified area. Different types of samples such as sludge samples (S1-S14, $n=13)$ and effluent samples $(n=7)$ from different tanneries located near to the Ranipet Common Treatment Plant and soil samples $(n=30)$ were collected from each location at three different depths. The samples at each point were collected at 10-20,30-40, and 45-60 cm, respectively. Sludge samples (S1-S9) were collected surrounding REETP, and sludge samples (S10-S13) were collected from the four corners of the rectangular shaped core sludge dumping spot. Basically S10 and S11 samples were collected from recently dumping spot, and S12 and S13 samples were collected from other side of the recently dumping area. All a-marked soil samples were collected at a depth of $10-20 \mathrm{~cm}$ from the surface, b-marked samples collected at a depth of $30-40 \mathrm{~cm}$, and c-marked samples collected at a depth of $45-60 \mathrm{~cm}$, respectively.

2.4. Sample Preparation. It was found that in optimum conditions of sequential extraction of soil the air-dried soil or drying of soil at $20-30^{\circ} \mathrm{C}$ should be used for effective determination of $\mathrm{Cr}$ in soil eluates. In higher drying temperatures $\mathrm{Cr}$ contained in soil created probably sparingly soluble compounds, which did not get easily into eluates with hydroxylamine hydrochloride $\left(\mathrm{NH}_{2} \mathrm{OH} \cdot \mathrm{HCl}\right)$ and hydrogen peroxide $\left(\mathrm{H}_{2} \mathrm{O}_{2}\right)$, causing distortion pattern of the actual $\mathrm{Cr}$ distribution in various metals fraction [39]. That's why, after the collection of soil samples they were air-dried at $30^{\circ} \mathrm{C}$ in a hot air oven until a constant weight was achieved. Also, Kalembkiewicz and Sočo [39] found that with an increase of grain diameter $(>0.25 \mathrm{~mm})$ the $\mathrm{Cr}$ concentration in eluates decreased. Thus, grain diameter of soil used for leaching should not be larger than $0.25 \mathrm{~mm}$. In the present study grain diameter of all samples were below $0.25 \mathrm{~mm}$. Then they were digested with nitric acid and hydrogen peroxide at $100^{\circ} \mathrm{C}$ for $2 \mathrm{hrs}$. Then digested sample was filtered using Supor membrane filters $(0.2 \mathrm{~mm}$ pore size, Sigma-Aldrich, MO, USA), and the filtrate was taken for the spectroscopic analysis. Sludge samples were subjected to SEP [40, 41]. Effluent samples were centrifuged and filtered before the digestion and analysis.

2.5. Analytical Procedure. Chemical speciation determines the potential environmental mobility and bioavailability of heavy metals in soil. Information about their physicochemical forms is thoroughly required for understanding the environmental behaviour (mobility, bioavailability, pathways) of heavy metals in soil. Sequential extraction procedures or fractionation have been widely applied to soils to know their chemical phase association [42]. Change in oxidation state, soil $\mathrm{pH}$, temperature, redox potential, soil organic matter decomposition, and so forth have a profound effect on its essentiality, toxicity, and bioavailability.

The sequential extraction procedure consists of a series of chemical extractants, each being more drastic in action and of different nature than the previous one [43]. As no reagent is single phase specific in element removal, sequentially extracted phases are "operationally" defined. The various selected phases include water soluble, exchangeable, carbonate and sulfide bound, reducible ( $\mathrm{Fe}$ and $\mathrm{Mn}$ oxide bound), oxidisable (organic matter bound), and residual (lattice bound). All phases except the residual one become available to biota under changing environmental conditions. To estimate the amount of $\mathrm{Cr}$ bound to different phases in soils and sludge, SEP was carried out using the following steps.

2.5.1. Collection of Water-Soluble Fraction. 2.0 grams of dry sample was weighed and taken in a $50 \mathrm{~mL}$ capped centrifugable bottle. The soil was dissolved in $50 \mathrm{~mL}$ water and mechanically shaken for $30 \mathrm{~min}$. Then it was centrifuged for 15 min at $3335 \times \mathrm{g}$ (REMI C-24BL, REMI Instruments Ltd, Mumbai, India) and the water-soluble fraction was collected. The residue was used for the collection of exchangeable fraction.

2.5.2. Collection of Exchangeable Fraction. $50 \mathrm{~mL}$ of $0.5 \mathrm{M}$ $\mathrm{Mg}\left(\mathrm{NO}_{3}\right)_{2}$ was added to the above residue and mechanically shaken for $30 \mathrm{~min}$. Then it was centrifuged for $15 \mathrm{~min}$ at $3335 \times \mathrm{g}$, and the exchangeable fraction was collected. The residue was used for the collection of carbonate and sulfide bound fraction.

2.5.3. Collection of Carbonate and Sulfide Bound (Weakly Absorbed/Acid Leachable) Fraction. $50 \mathrm{~mL}$ of $1 \mathrm{M} \mathrm{NaOAc}$ was added to the residue and mechanically shaken for $5 \mathrm{hrs}$. Then it was centrifuged for $15 \mathrm{~min}$ at $3335 \times \mathrm{g}$, and the carbonate and sulfide bound fraction was collected.

2.5.4. Collection of $\mathrm{Fe}$ and $\mathrm{Mn}$ Oxide Bound (Reducible) Fraction. $50 \mathrm{~mL}$ of $0.08 \mathrm{M} \mathrm{NH}_{2} \mathrm{OH} \cdot \mathrm{HCl}$ was added to the residue left after collection of carbonate and sulfide bound fraction and mechanically shaken for $6 \mathrm{hrs}$. Then it was centrifuged for $15 \mathrm{~min}$ at $3335 \times \mathrm{g}$, and the $\mathrm{Fe}$ and $\mathrm{Mn}$ oxide bound fraction was collected.

2.5.5. Collection of Organic Matter Bound (Oxidisable) Fraction. $10 \mathrm{~mL}$ of $\mathrm{H}_{2} \mathrm{O}_{2}$ was added to the residue left after collection of reducible fraction and heated for $2 \mathrm{hrs}$ at $85^{\circ} \mathrm{C}$. Then it was centrifuged for $15 \mathrm{~min}$ at $3335 \times \mathrm{g}$, and the organic matter bound fraction was collected. 
2.5.6. Collection of Lattice/Mineral Matrix Bound (Residual) Fraction. $5 \mathrm{~mL}$ of concentrated $\mathrm{HNO}_{3}$ was added to the residue left after collection of oxidisable fraction and heated for $2 \mathrm{hrs}$ at $105^{\circ} \mathrm{C}$. Then it was centrifuged for $15 \mathrm{~min}$ at $3335 \times \mathrm{g}$, and the mineral matrix phase was collected.

All samples were filtered through Supor membrane filters ( $0.2 \mathrm{~mm}$ pore size, Sigma-Aldrich, MO, USA) after sequential extraction and digestion. The samples were analyzed by UV-Visible Spectrophotometer (Schimadzu 8500 II, Tokyo, Japan). Standard Colorimetric Method 3500-D of American Public Health Association (APHA) for $\mathrm{Cr}$ analysis was adopted in the present study [38]. Standard Colorimetric Method 3500-D (APHA) consists of five steps depending on the nature of the samples. The present study used step 1 for calibration curve, step 3 for removal of interferences with cupferron, and step 5 for colour development and measurement of $\mathrm{Cr}$ content at $540 \mathrm{~nm}$ in all samples.

EPA 3050B method was used for the digestion of soil and sludge samples. In brief, for the digestion of samples, a representative 1-2 gram (wet weight) or 1 gram (dry weight) sample was digested with repeated additions of nitric acid $\left(\mathrm{HNO}_{3}\right)$ and hydrogen peroxide $\left(\mathrm{H}_{2} \mathrm{O}_{2}\right)$ and finally was diluted to $50 \mathrm{~mL}$ using doubled distilled water.

For microwave-assisted digestion of samples, a microwave digestion system (EM-S1563) from Sanyo Corporation, Mumbai, India with a rotor for fourteen Teflon digestion vessels HP-500, was used for sample digestion. Approximately $1.0 \mathrm{~g}$ of dry, finely powdered soil/sludge sample was weighed into a dry, clean Teflon digestion vessel. Two $\mathrm{mL}$ of MilliQ water, $3 \mathrm{~mL}$ of concentrated $\mathrm{HNO}_{3}$, and $2 \mathrm{~mL}$ of $\mathrm{H}_{2} \mathrm{O}_{2}$ were added. The vessel was closed, placed into the rotor, and tightened. The loaded rotor having maximum seven vessels per single time was placed into the microwave oven. The microwave conditions for three stage digestions were as follows. For stages $1-3$ the values of power (\%) $(600 \mathrm{~W})$ were $100 \mathrm{~s}$, PSI were 70, 120, 150; RAMP (min) were 20, 10, 10, and Hold (min) were $10 \mathrm{~s}$, respectively. After cooling for $30 \mathrm{~min}$, the vessels were opened carefully. Each digested solution was transferred quantitatively to a $50 \mathrm{~mL}$ volumetric flask and made up to the mark with Milli-Q water. Finally it was filtered through a millipore membrane $(0.45 \mu \mathrm{m})$ and kept in plastic container for analysis.

2.6. Statistical Analysis. All statistical works were done using StatView statistical software (StatView, SAS Institute Inc., Second Edition, USA, 1998). Student's $t$-test was used to test the null hypothesis that the means of the two groups are the same or not, and a significant $P$ value $(P<0.05)$ means are not the same. Statistical significant values were considered in all cases as $P<0.05$.

\section{Results and Discussion}

3.1. Total Chromium Concentration. The critical soil concentration or the critical load is defined as the range of values above which toxicity is considered to be possible. KabataPendias and Pendias [44] considered $75-100 \mathrm{mg} / \mathrm{kg}$ as critical value/load for chromium in soils. The concentration in the lowest soil horizon is commonly used to represent the natural background value, which is representative of individual soil profile [45].

For total Cr content all soils and sludge samples were digested by both EPA 3050 method and microwave digestion method. Sludge samples collected from the dumping site contained 377-1052 $\mu \mathrm{g} \mathrm{Cr} / \mathrm{g}$ sludge $(n=4)$ after acid digestion, whereas $413-1213 \mu \mathrm{g} \mathrm{Cr} / \mathrm{g}$ sludge $(n=4)$ after microwave digestion, whereas sludge samples collected from the tannery contained 492-2941 $\mu \mathrm{g} \mathrm{Cr} / \mathrm{g}$ sludge $(n=9)$ after acid digestion, whereas 490-3540 $\mu \mathrm{g} \mathrm{Cr} / \mathrm{g}$ sludge $(n=$ 9) after microwave digestion (raw data not shown). With respect to total $\mathrm{Cr}$ obtained in sludge samples by SEP the recovery of $\mathrm{Cr}$ was within the range of $96.2-114 \%$ by acid digestion and $87.2-108 \%$ by microwave digestion (raw data not shown). Soil samples collected from nearby agricultural lands contained $184-562 \mu \mathrm{g} \mathrm{Cr} / \mathrm{g}$ soil $(n=30)$ after acid digestion whereas $188-568 \mu \mathrm{g} \mathrm{Cr} / \mathrm{g}$ soil $(n=30)$ after microwave digestion, which is much lower than that of sludge samples. Similarly, with respect to total Cr obtained in soil samples by SEP, the recovery of Cr was within the range of $91.4-100 \%$ by acid digestion and $90-98.5 \%$ by microwave digestion (raw data not shown), respectively. Both methods gave almost similar recovery of $\mathrm{Cr}$ in sludge and soil samples in the present study.

The recovery results were comparable to the results of Chaudhary and Banerjee [42] (87.89 to $114.14 \%)$. In industrially contaminated land, $63-147 \%$ recovery was reported for $\mathrm{Cr}$ [46] which had a broad range of recovery compared to our results, whereas the metal concentration in the sludge was higher compared to that reported in Oake et al. [47].

Effluent samples collected from the tanneries contained about 7.5-45 $\mu \mathrm{g} \mathrm{Cr} / \mathrm{L}$ effluent ( $n=7$ ) (raw data not shown). This result suggests that a major fraction of $\mathrm{Cr}$ in soil might have leached and percolated to deeper layer which causes contamination of groundwater and subsequently highly prone to mobilization to the surrounding water layers as well as available to biota. The concentration of total chromium in the soil samples has decreased with the increase in the depth with few exceptional cases. Similarly, the concentration has decreased with the increase in distance between the dumping site and the sampling spot surrounding the agricultural field.

To get insights on $\mathrm{Cr}$ distribution in soils and sludge collected from the study area, the results of SEP study of sludge and soil samples are analyzed as fraction wise.

3.2. Water-Soluble Fraction. The concentration of $\mathrm{Cr}$ in water-soluble fraction was $19.8 \%$ in soils and $7.11 \%$ in sludge samples of the total Cr content (Tables 1 and 2). It clearly indicates that soils contain higher percentage of watersoluble $\mathrm{Cr}$ than that of $\mathrm{Cr}$ in sludge, and hence sludge is less prone to rain water leaching compared to soils. Although water-soluble fraction in sludge is comparatively less than that in soil, it is not recommendable to store tannery sludge in an open place for long run.

3.3. Exchangeable Fraction. The concentration of $\mathrm{Cr}$ in the exchangeable form decreases from the top to the bottom layer 
TABle 1: Concentration (Ave \pm Stdev, $n=3$ (in $\mu \mathrm{g} / \mathrm{g}$ )) of different forms of $\mathrm{Cr}$ in tannery sludge samples with sequential extraction.

\begin{tabular}{lccccccc}
\hline S. No & Water soluble & Exchangeable & Carbonate \& sulfide & Reducible fraction & Oxidisable fraction & Residual fraction & Total Cr \\
\hline S1 & $18.20 \pm 0.36$ & $194.2 \pm 1.11$ & $145.6 \pm 1.20$ & $24.27 \pm 0.32$ & $2275 \pm 3.84$ & $121.3 \pm 0.92$ & $2779 \pm 4.5$ \\
S2 & $52.79 \pm 0.48$ & $49.27 \pm 0.43$ & $172.5 \pm 1.40$ & $21.11 \pm 0.17$ & $586.5 \pm 1.61$ & $190.0 \pm 0.87$ & $1073 \pm 2.1$ \\
S3 & $75.12 \pm 0.53$ & $87.84 \pm 0.55$ & $179.1 \pm 0.87$ & $13.80 \pm 0.07$ & $577.9 \pm 2.13$ & $115.5 \pm 1.02$ & $1049 \pm 1.9$ \\
S4 & $70.15 \pm 0.44$ & $15.30 \pm 0.13$ & $159.4 \pm 0.82$ & $181.1 \pm 1.43$ & $797.1 \pm 2.34$ & $31.8 \pm 0.21$ & $1255 \pm 1.5$ \\
S5 & $57.36 \pm 0.37$ & $82.60 \pm 0.47$ & $91.78 \pm 0.43$ & $18.35 \pm 0.06$ & $186.1 \pm 1.82$ & $43.0 \pm 0.37$ & $479 \pm 1.1$ \\
S6 & $31.09 \pm 0.21$ & $163.2 \pm 1.33$ & $121.0 \pm 0.73$ & $26.43 \pm 0.12$ & $77.73 \pm 0.75$ & $330.3 \pm 3.34$ & $757 \pm 1.5$ \\
S7 & $150.6 \pm 0.73$ & $13.79 \pm 0.23$ & $97.84 \pm 0.64$ & $106.6 \pm 0.71$ & $47.03 \pm 0.64$ & $78.39 \pm 0.46$ & $494 \pm 0.8$ \\
S8 & $95.37 \pm 0.56$ & $47.69 \pm 0.51$ & $59.61 \pm 0.45$ & $38.15 \pm 0.38$ & $2578 \pm 4.31$ & $268.2 \pm 1.63$ & $3087 \pm 5.3$ \\
S9 & $68.58 \pm 0.49$ & $40.00 \pm 0.32$ & $133.7 \pm 0.94$ & $144.0 \pm 0.88$ & $77.44 \pm 0.74$ & $42.86 \pm 0.44$ & $500 \pm 1.2$ \\
S10 & $149.5 \pm 1.13$ & $58.53 \pm 0.61$ & $145.6 \pm 0.56$ & $87.85 \pm 0.82$ & $627.5 \pm 2.24$ & $31.37 \pm 0.65$ & $1100 \pm 2.5$ \\
S11 & $43.53 \pm 0.33$ & $180.3 \pm 0.97$ & $236.3 \pm 1.62$ & $205.2 \pm 1.26$ & $46.64 \pm 0.31$ & $155.4 \pm 1.12$ & $867 \pm 1.6$ \\
S12 & $86.23 \pm 0.62$ & $9.58 \pm 0.07$ & $119.8 \pm 1.53$ & $9.58 \pm 0.03$ & $59.88 \pm 0.27$ & $131.7 \pm 0.91$ & $416 \pm 0.9$ \\
S13 & $114.8 \pm 0.37$ & $31.20 \pm 0.08$ & $81.12 \pm 0.72$ & $21.22 \pm 0.05$ & $78.00 \pm 0.44$ & $62.40 \pm 0.38$ & $388 \pm 0.5$ \\
\hline
\end{tabular}

TABle 2: Concentration (Ave \pm Stdev, $n=3($ in $\mu \mathrm{g} / \mathrm{g})$ ) of different forms of Cr in soil samples with sequential extraction.

\begin{tabular}{|c|c|c|c|c|c|c|c|}
\hline S. No & Water soluble & Exchangeable & Carbonate \& sulfide & Reducible fraction & Oxidisable fraction & Residual fraction & Total Cr \\
\hline la & $51.85 \pm 0.34$ & $29.62 \pm 0.20$ & $17.28 \pm 0.30$ & $98.76 \pm 0.92$ & $55.55 \pm 0.32$ & $64.81 \pm 0.67$ & $317.9 \pm 2.1$ \\
\hline $1 b$ & $83.29 \pm 0.61$ & $36.74 \pm 0.60$ & $14.69 \pm 0.40$ & $102.8 \pm 1.20$ & $52.05 \pm 0.43$ & $42.87 \pm 0.41$ & $332.5 \pm 2.8$ \\
\hline $1 \mathrm{c}$ & $44.48 \pm 0.21$ & $23.47 \pm 0.05$ & $13.59 \pm 0.06$ & $98.86 \pm 0.58$ & $49.43 \pm 0.17$ & $24.70 \pm 0.04$ & $254.6 \pm 1.9$ \\
\hline $2 \mathrm{a}$ & $80.29 \pm 0.42$ & $29.29 \pm 0.15$ & $13.38 \pm 0.22$ & $105.8 \pm 0.73$ & $42.57 \pm 0.21$ & $36.49 \pm 0.35$ & $307.8 \pm 2.7$ \\
\hline $2 b$ & $49.11 \pm 0.33$ & $36.83 \pm 0.30$ & $19.64 \pm 0.33$ & $115.4 \pm 0.72$ & $30.69 \pm 0.41$ & $39.90 \pm 0.06$ & $291.6 \pm 0.9$ \\
\hline $2 c$ & $81.04 \pm 0.61$ & $12.27 \pm 0.60$ & $18.41 \pm 0.16$ & $103.1 \pm 0.80$ & $36.83 \pm 0.33$ & $61.39 \pm 0.61$ & $313.1 \pm 2.1$ \\
\hline $3 a$ & $57.09 \pm 0.23$ & $35.98 \pm 0.45$ & $17.36 \pm 0.23$ & $107.9 \pm 0.90$ & $34.11 \pm 0.31$ & $68.23 \pm 0.63$ & $327.7 \pm 1.7$ \\
\hline $3 b$ & $34.58 \pm 0.21$ & $44.33 \pm 0.21$ & $16.00 \pm 0.31$ & $108.3 \pm 0.32$ & $36.94 \pm 0.42$ & $36.94 \pm 0.32$ & $277.1 \pm 1.1$ \\
\hline $3 c$ & $22.55 \pm 0.09$ & $45.11 \pm 0.38$ & $42.60 \pm 0.62$ & $112.7 \pm 0.56$ & $43.85 \pm 0.26$ & $25.06 \pm 0.12$ & $291.9 \pm 0.7$ \\
\hline $4 a$ & $38.58 \pm 0.08$ & $13.78 \pm 0.30$ & $16.50 \pm 0.24$ & $26.18 \pm 0.32$ & $44.78 \pm 0.51$ & $31.00 \pm 0.05$ & $170.9 \pm 0.8$ \\
\hline $4 b$ & $47.52 \pm 0.11$ & $32.51 \pm 0.80$ & $27.59 \pm 0.14$ & $12.50 \pm 0.04$ & $28.13 \pm 0.44$ & $56.29 \pm 0.22$ & $204.5 \pm 1.3$ \\
\hline $4 \mathrm{c}$ & $33.46 \pm 0.05$ & $11.15 \pm 0.10$ & $26.77 \pm 0.72$ & $94.82 \pm 0.71$ & $25.93 \pm 0.07$ & $25.10 \pm 0.80$ & $217.3 \pm 1.4$ \\
\hline $5 a$ & $44.24 \pm 0.53$ & $34.41 \pm 0.70$ & $57.76 \pm 0.43$ & $110.7 \pm 0.48$ & $30.72 \pm 0.62$ & $18.43 \pm 0.22$ & $296.2 \pm 1.5$ \\
\hline $5 b$ & $32.08 \pm 0.33$ & $34.55 \pm 0.32$ & $25.91 \pm 0.41$ & $103.7 \pm 0.83$ & $49.35 \pm 0.70$ & $2.77 \pm 0.01$ & $240.3 \pm 2.0$ \\
\hline $5 c$ & $44.05 \pm 0.42$ & $31.81 \pm 0.27$ & $14.68 \pm 0.32$ & $99.11 \pm 0.37$ & $30.59 \pm 0.17$ & $48.94 \pm 0.42$ & $269.2 \pm 0.7$ \\
\hline $6 a$ & $37.34 \pm 0.06$ & $9.03 \pm 0.20$ & $25.20 \pm 0.13$ & $17.01 \pm 0.03$ & $42.00 \pm 0.51$ & $35.00 \pm 0.04$ & $218.9 \pm 1.4$ \\
\hline $6 \mathrm{~b}$ & $76.20 \pm 0.23$ & $29.49 \pm 0.61$ & $40.56 \pm 0.73$ & $307.2 \pm 1.31$ & $67.60 \pm 0.48$ & $30.70 \pm 0.18$ & $551.9 \pm 2.3$ \\
\hline $6 c$ & $116.7 \pm 0.92$ & $26.20 \pm 0.39$ & $17.86 \pm 0.44$ & $78.60 \pm 0.43$ & $29.71 \pm 0.32$ & $29.77 \pm 0.27$ & $298.9 \pm 1.7$ \\
\hline $7 \mathrm{a}$ & $36.63 \pm 0.07$ & $29.37 \pm 0.26$ & $40.30 \pm 0.72$ & $102.5 \pm 0.72$ & $30.53 \pm 0.05$ & $39.69 \pm 0.62$ & $279.1 \pm 1.5$ \\
\hline $7 \mathrm{~b}$ & $32.40 \pm 0.05$ & $44.86 \pm 0.32$ & $29.91 \pm 0.51$ & $112.1 \pm 0.61$ & $37.38 \pm 0.44$ & $24.90 \pm 0.20$ & $281.6 \pm 1.2$ \\
\hline $7 \mathrm{c}$ & $50.69 \pm 0.61$ & $34.61 \pm 0.27$ & $17.30 \pm 0.04$ & $92.72 \pm 0.47$ & $28.43 \pm 0.37$ & $40.18 \pm 0.51$ & $264.0 \pm 1.7$ \\
\hline $8 a$ & $62.98 \pm 0.45$ & $53.29 \pm 0.42$ & $25.43 \pm 0.64$ & $17.25 \pm 0.04$ & $33.30 \pm 0.41$ & $27.25 \pm 0.31$ & $272.3 \pm 1.1$ \\
\hline $8 b$ & $36.37 \pm 0.34$ & $12.12 \pm 0.33$ & $13.33 \pm 0.06$ & $12.12 \pm 0.03$ & $48.49 \pm 0.60$ & $16.62 \pm 0.05$ & $183.1 \pm 0.6$ \\
\hline $8 c$ & $29.62 \pm 0.21$ & $24.69 \pm 0.50$ & $59.25 \pm 0.76$ & $29.62 \pm 0.12$ & $37.03 \pm 0.42$ & $21.60 \pm 0.03$ & $201.8 \pm 0.9$ \\
\hline $9 a$ & $27.03 \pm 0.13$ & $49.23 \pm 0.52$ & $35.15 \pm 0.04$ & $81.24 \pm 0.64$ & $55.39 \pm 0.42$ & $52.31 \pm 0.71$ & $303.4 \pm 1.0$ \\
\hline $9 b$ & $42.22 \pm 0.37$ & $37.25 \pm 0.24$ & $24.83 \pm 0.11$ & $99.35 \pm 0.83$ & $31.04 \pm 0.53$ & $27.94 \pm 0.50$ & $262.7 \pm 0.5$ \\
\hline $9 c$ & $287.2 \pm 2.10$ & $12.04 \pm 0.10$ & $66.26 \pm 0.63$ & $93.97 \pm 0.53$ & $33.13 \pm 0.04$ & $21.08 \pm 0.07$ & $515.7 \pm 1.7$ \\
\hline $10 \mathrm{a}$ & $46.29 \pm 0.70$ & $37.03 \pm 0.70$ & $27.77 \pm 0.32$ & $115.7 \pm 0.74$ & $57.89 \pm 0.08$ & $57.87 \pm 0.53$ & $342.6 \pm 1.4$ \\
\hline $10 \mathrm{~b}$ & $33.80 \pm 0.40$ & $31.38 \pm 0.30$ & $26.55 \pm 0.06$ & $96.75 \pm 0.44$ & $36.21 \pm 0.33$ & $51.30 \pm 0.42$ & $275.8 \pm 1.3$ \\
\hline $10 \mathrm{c}$ & $27.39 \pm 0.53$ & $48.99 \pm 0.44$ & $34.29 \pm 0.16$ & $17.54 \pm 0.34$ & $42.87 \pm 0.51$ & $51.31 \pm 0.87$ & $180.0 \pm 0.7$ \\
\hline
\end{tabular}


of the soil strata and decreases with decrease in $\mathrm{pH}$. Thus it can be interpreted that, in cases where $\mathrm{pH}$ is acidic, the concentration of exchangeable fraction is less than in those having alkaline $\mathrm{pH}$. This may be due to $\mathrm{Cr}(\mathrm{VI})$ reduction to $\mathrm{Cr}$ (III) at acidic pH, which is the immobile form. Similar findings were reported by Cary et al. [48], and the reduction of $\mathrm{Cr}(\mathrm{VI})$ was more rapid in acid than in alkaline soils, and hence soluble $\mathrm{Cr}$ (III) was rapidly transformed to its mobile forms due to complex formation with humus substances present in the soils immediately after reduction. Another report [46] found that solubility of $\mathrm{Cr}$ (III) decreased as the solution pH increased above 5 and eventually $\mathrm{Cr}$ (III) showed complete precipitation at $\mathrm{pH}$ 5.5. In this study, exchangeable Cr was $6.8 \%$ and $10.9 \%$ of total $\mathrm{Cr}$ content in soils and sludge, respectively, (Tables 1 and 2), which was comparable to other reports $[42,49-51]$.

\subsection{Carbonate and Sulfide-Bound Fraction (Weakly Absorbed/} Acid Leachable Fraction). Trace metals may coprecipitate with carbonate and sulfide both inorganically and biologically. This fraction is highly susceptible to $\mathrm{pH}$ changes [23]. The carbonate bound fraction accounted for a relatively small amount of total Cr concentration in soils (9.7\%) compared to a relatively higher amount of total $\mathrm{Cr}$ concentration in sludge $(12.2 \%)$ and decreased slightly downwards from the soil surface in the present study (Tables 1 and 2). These results clearly matched with the results of previous workers $[42,51]$. Although acid leachable fraction was about $10 \%$ of total Cr content, it still possesses threat in acidic soils or acidcontaminated environment.

\subsection{Reducible Fraction (Iron and Manganese Oxide Bound} Fraction). Chromium(III) oxidation in soil increased with $\mathrm{Mn}(\mathrm{IV})$ oxides content of the soil [52]. Under certain circumstances $\mathrm{Cr}$ (III) could be oxidized to more mobile and toxic $\mathrm{Cr}(\mathrm{VI})$ in soils containing Mn oxide [53, 54]. Nonhumic organic substances such as carbohydrates and proteins [55], and Organic matter can reduce $\mathrm{Cr}(\mathrm{VI})$ in soils $[56,57]$. Hence iron and Mn oxides can retain substantial amounts of metals and play an important role in controlling the fate of heavy metal mobility in the environment [58]. Theoretically, this fraction represents the content of metal bound to iron and manganese oxides that would be released if the sediment experienced more reducing environment [59]. In the present study, the concentration of $\mathrm{Cr}$ in this phase was $31.3 \%$ in soils and 6.3\% of the total Cr content in sludge (Tables 1 and 2 ). On an average the amount of chromium in $\mathrm{Fe}$ - and $\mathrm{Mn}$ oxide bound fraction was $69.1 \mu \mathrm{g} / \mathrm{g}$ of sludge (Table 1 ). This fraction of $\mathrm{Cr}$ is not bioavailable to plants and biota, that is, immobile in nature.

Higher concentration of $\mathrm{Cr}$ in the reducible phase suggests close association of it with Fe-Mn oxides and in situ changes in $\mathrm{pH}$ or redox potential could easily mobilize $\mathrm{Cr}$ associated with reducible phase. The high percentage of total $\mathrm{Cr}$ in this fraction proposes that Fe-Mn bound phase acts as a scavenger of $\mathrm{Cr}$ in polluted soils. So the mobility of this fraction should be monitored critically. Otherwise this portion will spread over throughout underground basin and may contaminate easily surrounding areas under variable environmental settings.

3.6. Oxidizable Fraction (Organic-Bound Fraction). Normally tannery effluents, sludge, and soils surrounding these tanneries are rich in organic matters due to lack of treatment technologies of wastes generated in tanneries. Trace metals bound to various forms of organic matter (living organisms, detritus coating on mineral particles) were extracted in this fraction. In the present study, organic matter bound fraction was $616 \mu \mathrm{g} / \mathrm{g}$ of sludge, and oxidisable $\mathrm{Cr}$ in sludge was $56.3 \%$ of the total $\mathrm{Cr}$ content which was higher than the other profiles, but soils had $14.1 \%$ oxidisable $\mathrm{Cr}$ of the total $\mathrm{Cr}$ content (Tables 1 and 2). These variations seem to be controlled by total organic carbon content and can be ascribed to the fact that organic matter present in the soil acts as an electron donor and thus provides favourable conditions for the reduction of $\mathrm{Cr}$ (VI) to $\mathrm{Cr}$ (III) [46]. The organic matter consumed by microbial activity can cause release of organic acids due to degradation process and thus a decrease in $\mathrm{pH}$. This would affect speciation of $\mathrm{Cr}$, as a lower $\mathrm{pH}$ would favour $\mathrm{Cr}$ (III). The $\mathrm{Cr}$ (III) so formed has a capability to form soluble organic complexes, which are mobile in nature and show their presence as high organic bound $\mathrm{Cr}$ in this fraction. The decrease in carbon content with depth causes decrease of complexation of $\mathrm{Cr}$ and hence its concentration decreases in this fraction. This concept clearly clarifies the presence of high organic bound fraction in contaminated soils near mining area (13\%) [33] and in industrially contaminated land (19\%) [50], since all these areas contain less organic carbon that is rich in inorganic materials. As high as $70 \%$ of total $\mathrm{Cr}$ in oxidisable phase has been found in tannery wastewater irrigated land [60]. The high percentage of $\mathrm{Cr}$ in sludge indicates that sludge is richer in organic matter than that of soils which is highly reasonable due to absorption of fatty acids, amino acids as well as contamination of muscles, and skin residues during the settling of effluents.

3.7. Residual Fraction (Lattice-Bound Fraction). The $\mathrm{Cr}$ concentration in mineral matrix was $123 \mu \mathrm{g} / \mathrm{g}$ of sludge, which was fully immobile in nature for long run. The lower percentages of the total $\mathrm{Cr}$ content in residual fraction in soils $(13 \%)$ and sludge $(11.3 \%)$ were in strong agreement with the results obtained by Rauret et al. [61] (Tables 1 and 2 ). This phase is a chemically inert fraction and may not be easily accessible to biota. So, this fraction of $\mathrm{Cr}$ does not pose any threat to environment. Although the easily available exchangeable form in this sludge constitutes only $10.9 \%$, the actual $\mathrm{Cr}$ content corresponding to this form may be elevated for the disposal of the sludge in the environment. In contaminated sites the concentration of $\mathrm{Cr}$ was found to be higher in the reducible phase in soils (31.3\%) and oxidisable phases in sludge (56.3\%) (Tables 1 and 2).

Typically metals of anthropogenic inputs tend to reside in the first four fractions, and metals found in the residual fraction are of natural occurrence in the parent rock [30]. So speciation of chromium is essential for research on $\mathrm{Cr}$ 
mobility. A few reports on SEPs informed combining the exchangeable and carbonate-bound fractions in a single step [34] or dividing the $\mathrm{Fe}$ and $\mathrm{Mn}$ oxide fractions into the amorphous oxyhydroxides and crystalline oxides [43] or including EDTA extractable, moderately reducible, and strongly reducible fractions [62] or even nine fractions for testing waste amended and agriculturally polluted sediments [63]. Although fractions and chemicals used were different for different studies using SEPs all $[29,30,32,64]$ found the same order of extraction of metals as $\mathrm{Cd}>\mathrm{Pb}>\mathrm{Zn} \approx \mathrm{Cu}>$ $\mathrm{Mn}>\mathrm{Ni}>\mathrm{Fe} \approx \mathrm{Cr}$. Other important findings were that metals collected for fractions 1-3 were less than expected and for fractions 4-5 were greater than expected. In the present study, the sum of first three fractions is $36.3 \%$ in soils and $30.2 \%$ in sludge, whereas the sum of 4 th and 5 th fractions is $45.4 \%$ in soils and $62.6 \%$ in sludge. Although these results supported the above statement, more thorough research will be needed to address whether metals such as $\mathrm{Cu}, \mathrm{Mn}, \mathrm{Ni}$, $\mathrm{Pb}, \mathrm{V}$, and $\mathrm{Zn}$ that released in the first three fractions were reattaching to the newly available sites of the next fraction [37] with varying soil composition and the nature of the metal. Consequently the fractional quantification will be skewed toward lower than real results for the fractions related to first three fractions and skewed toward higher than real results for 4th and 5th fractions [30,37].

The present study gave some important findings. An increasing trend was observed when average concentrations of $\mathrm{Cr}$ were plotted against different sequential fractions in sludge samples. It clearly shows that the value of organic matter and sulfide bound $\mathrm{Cr}$ (fraction 5) was maximum in the sludge samples (Figure 1(a)), but it was not conclusive when average concentrations of $\mathrm{Cr}$ were plotted against different sequential fractions in soil samples (Figure 1(b)). In the case of soil samples the highest value of $\mathrm{Fe}-\mathrm{Mn}$ bound $\mathrm{Cr}$ was found among other fractions. Higher concentration of $\mathrm{Cr}$ in the reducible phase suggests close association of it with $\mathrm{Fe}-\mathrm{Mn}$ oxides and in situ changes in $\mathrm{pH}$ or redox potential could easily mobilize $\mathrm{Cr}$ associated with reducible phase. The high percentages of total $\mathrm{Cr}$ in this fraction $(31.3 \%$ in soil and $6.3 \%$ in sludge) show that Fe-Mn bound phase acts as scavenger of $\mathrm{Cr}$ in polluted soils. The present result is highly comparable to the result of Chaudhary and Banerjee [42]. The present result indicates that iron rich soil can hold $\mathrm{Cr}$ which will be available to plants and biota under favorable environmental conditions.

Also, this study shows that about $63.7 \%$ of total $\mathrm{Cr}$ is mobilisable and $36.3 \%$ of total $\mathrm{Cr}$ is nonbioavailable in soil, whereas about $30.2 \%$ of total $\mathrm{Cr}$ is mobilisable and $69.8 \%$ of total $\mathrm{Cr}$ is nonbioavailable in sludge. But under oxidisable conditions $14.1 \%$ of total $\mathrm{Cr}$ in soil and $56.3 \%$ of total $\mathrm{Cr}$ in sludge (fraction 5), that is, organic bound $\mathrm{Cr}$ are mobilisable due to degradation of organic substances by microorganisms (Tables 1 and 2).

In addition, $\mathrm{Cr}$ (III) will form soluble complexes in acidic conditions, which are mobile in nature. Only 13\% of total $\mathrm{Cr}$ was in the residual phase in soil (fraction 6), and 11.3\% of total $\mathrm{Cr}$ was in the residual phase in sludge (fraction 6), which are stable and absolutely immobile in nature. Inversely, on an average water-soluble fraction, exchangeable

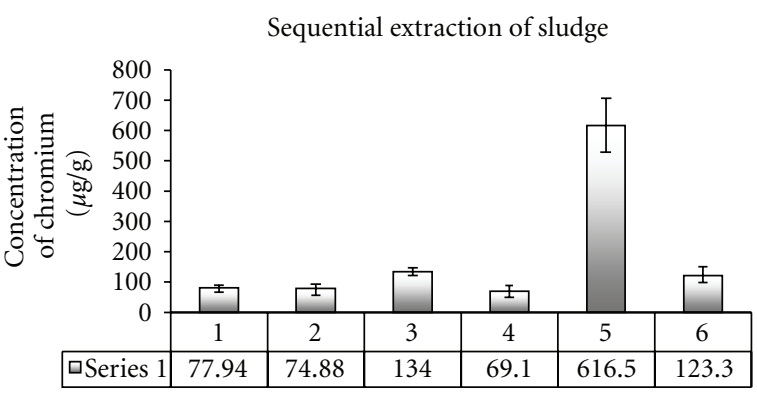

Different fractions

(a)

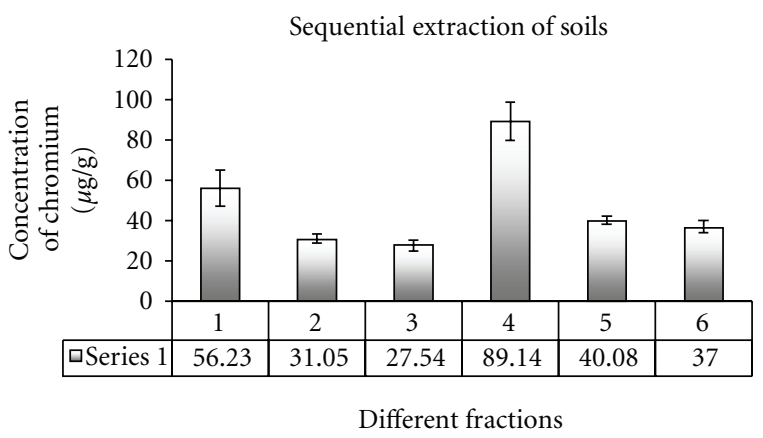

(b)

Figure 1: Bar diagram of average concentrations of $\mathrm{Cr}$ (in $\mu \mathrm{g} / \mathrm{g}$ ) in different sequential extracted fractions (along $Y$-axis) versus types of extractants (along $X$-axis) in (a) tannery sludge and (b) agricultural soils. (1) Water-soluble fraction, (2) exchangeable fraction, (3) carbonate and sulfide bound fraction, (4) Fe and $\mathrm{Mn}$ oxide bound fraction, (5) organic matter bound fraction, and (6) mineral matrix bound fraction.

fraction and carbonate-bound fraction contained 77.9, 74.9 and $134 \mu \mathrm{g} / \mathrm{g}(n=13)$ in sludge samples, respectively (Table 1). This easily leachable and mobilisable $\mathrm{Cr}$ is easily available to plant and biota intake as well as contamination of groundwater.

\section{Conclusions}

The results of the present study clearly indicate that there is a possibility of $\mathrm{Cr}$ percolation into the ground water, which may lead to many health hazards and disturb the surrounding livelihoods. Also, the dumping of tannery sludge in an open land is not safe for ecosystem due to degradation with time under normal environmental conditions. The results of $\mathrm{Cr}$ content and speciation profile of both the sludge and soils indicate that it may not be safe to dispose the sludge on barren land and in water bodies as well as land filling. Thus one of the viable alternatives is the effective recovery of $\mathrm{Cr}$ from the sludge before dumping in an open field. Since there is discrepancy in results due to nonselective reagents and other uncertainties, proper selection of reagents coupled with XRD would be promising research areas for understanding of metal bound chemistry in soils and sludge. So a suitable and proper management of handling tannery 
sludge in the said area is urgently needed to save the surrounding environment as well as ecosystems.

\section{Acknowledgment}

Dr. Badal Kumar Mandal and other authors acknowledge the help of VIT University, Vellore 632014 for the financial support and laboratory facilities to carry out this research works.

\section{References}

[1] World Health Organization, "Health criteria and other supporting information," in Guidelines for Drinking-Water Quality, pp. 206-215, World Health Organization, Geneva, Switzerland, 1996.

[2] A. Baral and R. D. Engelken, "Chromium-based regulations and greening in metal finishing industries in the USA," Environmental Science and Policy, vol. 5, no. 2, pp. 121-133, 2002.

[3] A. K. Bera and K. Bokaria, "Effect of tannery effluents on seed germination, seedling growth and chloroplast pigment content in mungbean (Vigna radiata L. Wilczek)," Environmental Ecology, vol. 17, no. 4, pp. 958-961, 1999.

[4] A. Gupta and P. Sujatha, "Tannery effluent characteristics and its effects on agriculture," Journal of Ecotoxicology and Environmental Monitoring, vol. 6, no. 1, pp. 45-48, 1996.

[5] M. Ziagova, G. Dimitriadis, D. Aslanidou, X. Papaioannou, E. Litopoulou Tzannetaki, and M. Liakopoulou-Kyriakides, "Comparative study of $\mathrm{Cd}(\mathrm{II})$ and $\mathrm{Cr}(\mathrm{VI})$ biosorption on Staphylococcus xylosus and Pseudomonas sp. in single and binary mixtures," Bioresource Technology, vol. 98, no. 15, pp. 2859-2865, 2007.

[6] D. Park, S. R. Lim, Y. S. Yun, and J. M. Park, "Reliable evidences that the removal mechanism of hexavalent chromium by natural biomaterials is adsorption-coupled reduction," Chemosphere, vol. 70, no. 2, pp. 298-305, 2007.

[7] M. K. Banks, A. P. Schwab, and C. Henderson, "Leaching and reduction of chromium in soil as affected by soil organic content and plants," Chemosphere, vol. 62, no. 2, pp. 255-264, 2006.

[8] M. V. Aldrich, J. L. Gardea-Torresdey, J. R. Peralta-Videa, and J. G. Parsons, "Uptake and reduction of $\mathrm{Cr}(\mathrm{VI})$ to $\mathrm{Cr}(\mathrm{III})$ by mesquite (Prosopis spp.): chromate-plant interaction in hydroponics and solid media studied using XAS," Environmental Science and Technology, vol. 37, no. 9, pp. 1859-1864, 2003.

[9] G. J. Puzon, R. K. Tokala, H. Zhang, D. Yonge, B. M. Peyton, and L. Xun, "Mobility and recalcitrance of organochromium(III) complexes," Chemosphere, vol. 70, no. 11, pp. 2054-2059, 2008.

[10] A. Flores and J. M. Pérez, "Cytotoxicity, apoptosis, and in vitro DNA damage induced by potassium chromate," Toxicology and Applied Pharmacology, vol. 161, no. 1, pp. 75-81, 1999.

[11] J. H. Priester, S. G. Olson, S. M. Webb, M. P. Neu, L. E. Hersman, and P. A. Holden, "Enhanced exopolymer production and chromium stabilization in Pseudomonas putida unsaturated biofilms," Applied and Environmental Microbiology, vol. 72, no. 3, pp. 1988-1996, 2006.

[12] J. M. Zachara, D. C. Girvin, R. L. Schmidt, and C. T. Resch, "Chromate adsorption on amorphous iron oxyhydroxide in the presence of major groundwater ions," Environmental Science and Technology, vol. 21, no. 6, pp. 589-594, 1987.
[13] M. B. Aceves, H. E. Santos, J. D. R. Berber, J. L. O. Mota, and R. R. Vázquez, "Distribution and mobility of Cr in tannery waste amended semi-arid soils under simulated rainfall," Journal of Hazardous Materials, vol. 171, no. 1-3, pp. 851-858, 2009.

[14] J. R. Kiser and B. A. Manning, "Reduction and immobilization of chromium(VI) by iron(II)-treated faujasite," Journal of Hazardous Materials, vol. 174, no. 1-3, pp. 167-174, 2010.

[15] J. Markiewicz-Patkowska, A. Hursthouse, and H. Przybyla-Kij, "The interaction of heavy metals with urban soils: sorption behaviour of $\mathrm{Cd}, \mathrm{Cu}, \mathrm{Cr}, \mathrm{Pb}$ and $\mathrm{Zn}$ with a typical mixed brownfield deposit," Environment International, vol. 31, no. 4, pp. 513-521, 2005.

[16] A. D. Covington and R. L. Sykes, "A practical chrome recovery system using magnesium oxide," Journal of the Society of Leather Technologists and Chemists, vol. 67, no. 1, pp. 5-12, 1983.

[17] M. L. Silveira, L. R. F. Alleoni, G. A. O'Connor, and A. C. Chang, "Heavy metal sequential extraction methods-A modification for tropical soils," Chemosphere, vol. 64, no. 11, pp. 1929-1938, 2006.

[18] M. Raju and S. N. Tandon, "Operationally determined speciation of chromium in tannery sludges," Chemical Speciation and Bioavailability, vol. 11, no. 2, pp. 67-70, 1999.

[19] S. J. Dreiss, "Chromium migration through sludge-treated soils," Ground Water, vol. 24, no. 3, pp. 312-321, 1986.

[20] R. S. Makdisi, "Tannery wastes definition, risk assessment and cleanup options, Berkeley, California," Journal of Hazardous Materials, vol. 29, no. 1, pp. 79-96, 1991.

[21] D. Mohan, K. P. Singh, and V. K. Singh, "Trivalent chromium removal from wastewater using low cost activated carbon derived from agricultural waste material and activated carbon fabric cloth," Journal of Hazardous Materials, vol. 135, no. 1-3, pp. 280-295, 2006.

[22] L. Kennedy, "Cooperating for survival: tannery pollution and joint action in the Palar Valley (India)," World Development, vol. 27, no. 9, pp. 1673-1691, 1999.

[23] A. Tessier, P. G. C. Campbell, and M. Blsson, "Sequential extraction procedure for the speciation of particulate trace metals," Analytical Chemistry, vol. 51, no. 7, pp. 844-851, 1979.

[24] E. J. Elzinga and A. Cirmo, "Application of sequential extractions and X-ray absorption spectroscopy to determine the speciation of chromium in Northern New Jersey marsh soils developed in chromite ore processing residue (COPR)," Journal of Hazardous Materials, vol. 183, no. 1-3, pp. 145-154, 2010.

[25] X. P. Wang, X. Q. Shan, S. Z. Zhang, and B. Wen, "A model for evaluation of the phytoavailability of trace elements to vegetables under the field conditions," Chemosphere, vol. 55, no. 6, pp. 811-822, 2004.

[26] E. E. Cary, W. H. Allaway, and O. E. Olson, "Control of chromium concentrations in food plants. 1. Absorption and translocation of chromium by plants," Journal of Agricultural and Food Chemistry, vol. 25, no. 2, pp. 300-304, 1977.

[27] M. M. Lasat, "Phytoextraction of toxic metals: a review of biological mechanisms," Journal of Environmental Quality, vol. 31, no. 1, pp. 109-120, 2002.

[28] D. C. Adriano, Trace Elements in the Terrestrial Environment, Springer, New York, NY, USA, 1986.

[29] F. M. G. Tack and M. G. Verloo, "Chemical speciation and fractionation in soil and sediment heavy metal analysis: a review," International Journal of Environmental Analytical Chemistry, vol. 59, pp. 225-238, 1995. 
[30] T. Ratuzny, Z. Gong, and B. M. Wilke, "Total concentrations and speciation of heavy metals in soils of the Shenyang Zhangshi Irrigation Area, China," Environmental Monitoring and Assessment, vol. 156, no. 1-4, pp. 171-180, 2009.

[31] B. K. Mandal, K. T. Suzuki, K. Anzai, K. Yamaguchi, and Y. Sei, "A SEC-HPLC-ICP MS hyphenated technique for identification of sulfur-containing arsenic metabolites in biological samples," Journal of Chromatography B, vol. 874, no. 1-2, pp. 64-76, 2008.

[32] D. Sarkar and R. Datta, "Arsenic fate and bioavailability in two soils contaminated with sodium arsenate pesticide: an incubation study," Bulletin of Environmental Contamination and Toxicology, vol. 72, no. 2, pp. 240-247, 2004.

[33] I. Maiz, I. Arambarri, R. Garcia, and E. Millán, "Evaluation of heavy metal availability in polluted soils by two sequential extraction procedures using factor analysis," Environmental Pollution, vol. 110, no. 1, pp. 3-9, 2000.

[34] A. M. Ure, P. H. Quevauviller, H. Muntau, and B. Griepink, "Speciation of heavy metals in soils and sediments. An account of the improvement and harmonization of extraction techniques undertaken under the auspices of the BCR of the commission of the European communities," International Journal of Environmental Analytical Chemistry, vol. 51, pp. 135-151, 1993.

[35] E. Galan, J. L. Gomez Ariza, I. Gonzalez, J. C. Fernandez Caliani, E. Morales, and I. Giraldez, "Utilidad de las tecnicas de extraccion secuencial en la mejora de la caracterización mineralogica por DRX de suelos y sedimentos con altos contenidos de oxidos de hierro," in Libro de Conferencias y Resumenes de la XV Reunion Cientifica de la Sociedad Española de Arcillas, vol. 15, pp. 68-69, 1999.

[36] E. Doelsch, G. Moussard, and H. S. Macary, "Fractionation of tropical soilborne heavy metals-Comparison of two sequential extraction procedures," Geoderma, vol. 143, no. 1-2, pp. 168179,2008

[37] A. J. Zimmerman and D. C. Weindorf, "Heavy metal and trace metal analysis in soil by sequential extraction: a review of procedures," International Journal of Analytical Chemistry, vol. 2010, Article ID 387803, 7 pages, 2010.

[38] APHA, WEF, AWWA, Standard Methods for Examination of Water and Wastewater, APHA, Washington, DC, USA, 19th edition, 1995.

[39] J. Kalembkiewicz and E. Sočo, "Investigations of sequential extraction of chromium from soil," Polish Journal of Environmental Studies, vol. 11, no. 3, pp. 245-250, 2002.

[40] P. Bhattacharyya, A. Chakraborty, B. Bhattacharya, and K. Chakrabarti, "Evaluation of municipal solid waste compost as a component of integrated nutrient management in rain fed wetland rice," Compost Science and Utilization, vol. 11, pp. 245-250, 2003.

[41] P. Bhattacharyya, K. Chakrabarti, and A. Chakraborty, "Microbial biomass and enzyme activities in submerged rice soil amended with municipal solid waste compost and decomposed cow manure," Chemosphere, vol. 60, no. 3, pp. 310-318, 2005.

[42] S. Chaudhary and D. K. Banerjee, "Metal phase association of chromium in contaminate Mohan, D., Singh, K.P., Singh, V.K. 2006.d soils from an industrial area in Delhi," Chemical Speciation and Bioavailability, vol. 16, no. 4, pp. 145-150, 2004.

[43] G. E. M. Hall, J. E. Vaive, R. Beer, and M. Hoashi, "Selective leaches revisited, with emphasis on the amorphous Fe oxyhydroxide phase extraction," Journal of Geochemical Exploration, vol. 56, no. 1, pp. 59-78, 1996.
[44] A. Kabata-Pendias and H. Pendias, Trace Elements in Soils and Plants, CRC Press, Boca Raton, Fla, USA, 1992.

[45] P. Blaser, S. Zimmermann, J. Luster, and W. Shotyk, "Critical examination of trace element enrichments and depletions in soils: as, $\mathrm{Cr}, \mathrm{Cu}, \mathrm{Ni}, \mathrm{Pb}$, and $\mathrm{Zn}$ in Swiss forest soils," Science of the Total Environment, vol. 249, no. 1-3, pp. 257-280, 2000.

[46] B. R. James and R. J. Bartlett, "Behavior of chromium in soils. VI. Interactions between oxidation-reduction and organic complexation," Journal of Environmental Quality, vol. 12, no. 2, pp. 173-176, 1983.

[47] R. J. Oake, C. S. Booker, and R. D. Davis, "Fractionation of heavy metals in sewage sludges," Water Science and Technology, vol. 17 , no. 4-5, pp. 587-598, 1985.

[48] E. E. Cary, W. H. Allaway, and O. E. Olson, "Control of chromium concentrations in food plants. 1. Absorption and translocation of chromium by plants," Journal of Agricultural and Food Chemistry, vol. 25, no. 2, pp. 300-304, 1977.

[49] B. R. James, "Hexavalent chromium solubility and reduction in alkaline soils enriched with chromite ore processing residue," Journal of Environmental Quality, vol. 23, no. 2, pp. 227-233, 1994.

[50] C. M. Davidson, A. L. Duncan, D. Littlejohn, A. M. Ure, and L. M. Garden, "A critical evaluation of the three-stage BCR sequential extraction procedure to assess the potential mobility and toxicity of heavy metals in industrially-contaminated land," Analytica Chimica Acta, vol. 363, no. 1, pp. 45-55, 1998.

[51] M. J. Belzunce-Segarra, J. R. Bacon, R. Prego, and M. J. Wilson, "Chemical forms of heavy metals in surface sediments of the San Simón inlet, Ría de Vigo, Galicia," Journal of Environmental Science and Health, vol. 32, no. 5, pp. 12711292, 1997.

[52] J. G. Kim and J. B. Dixon, "Oxidation and fate of chromium in soils," Soil Science and Plant Nutrition, vol. 48, no. 4, pp. 483-490, 2002.

[53] Y. M. Tzou, R. H. Loeppert, and M. K. Wang, "Effect of organic complexing ligands on $\mathrm{Cr}(\mathrm{III})$ oxidation by MnOx," Soil Science, vol. 167, no. 11, pp. 729-738, 2002.

[54] P. Chandra and K. Kulshreshtha, "Chromium accumulation and toxicity in aquatic vascular plants," Botanical Review, vol. 70, no. 3, pp. 313-327, 2004.

[55] N. S. Bolan and S. Thiagarajan, "Retention and plant availability of chromium in soils as affected by lime and organic matter amendments," Australian Journal of Soil Research, vol. 39, no. 5, pp. 1091-1103, 2001.

[56] N. Kožuh, J. Štupar, and B. Gorenc, "Reduction and oxidation processes of chromium in soils," Environmental Science and Technology, vol. 34, no. 1, pp. 112-119, 2000.

[57] N. S. Bolan, D. C. Adriano, R. Natesan, and B. J. Koo, "Effects of organic amendments on the reduction and phytoavailability of chromate in mineral soil," Journal of Environmental Quality, vol. 32, no. 1, pp. 120-128, 2003.

[58] S. Yu, Z. L. He, C. Y. Huang, G. C. Chen, and D. V. Calvert, "Copper fractionation and extractability in two contaminated variable charge soils," Geoderma, vol. 123, no. 1-2, pp. 163175, 2004.

[59] D. Panda, V. Subramanian, and R. C. Panigrahy, "Geochemical fractionation of heavy metals in Chilka Lake (east coast of India)-a tropical coastal lagoon," Environmental Geology, vol. 26, no. 4, pp. 199-210, 1995.

[60] M. A. Armienta, O. Morton, R. Rodríguez, O. Cruz, A. Aguayo, and N. Ceniceros, "Chromium in a tannery wastewater irrigated area, León Valley, Mexico," Bulletin of Environmental Contamination and Toxicology, vol. 66, no. 2, pp. 189-195, 2001 
[61] G. Rauret, R. Rubio, J. F. Lopez-Sanchez, and E. Casassas, "Specific procedure for metal solid speciation in heavily polluted river sediments," International Journal of Environmental Analytical Chemistry, vol. 35, no. 2, pp. 89-100, 1989.

[62] H. Zeien and G. W. Brummer, "Chemische extraktion zur bestimmung von schwermetallbindungsformen in boden," Metteilungen der Deutschen Bodenkundlichen Gesellschaft, vol. 39, pp. 505-510, 1989.

[63] W. P. Miller, D. C. Martens, and L. W. Zelazny, "Effect of sequence in extraction of trace metals from soils," Soil Science Society of America Journal, vol. 50, no. 3, pp. 598-601, 1986.

[64] J. Kierczak, C. Neel, U. Aleksander-Kwaterczak, E. HeliosRybicka, H. Bril, and J. Puziewicz, "Solid speciation and mobility of potentially toxic elements from natural and contaminated soils: a combined approach," Chemosphere, vol. 73, no. 5, pp. 776-784, 2008. 

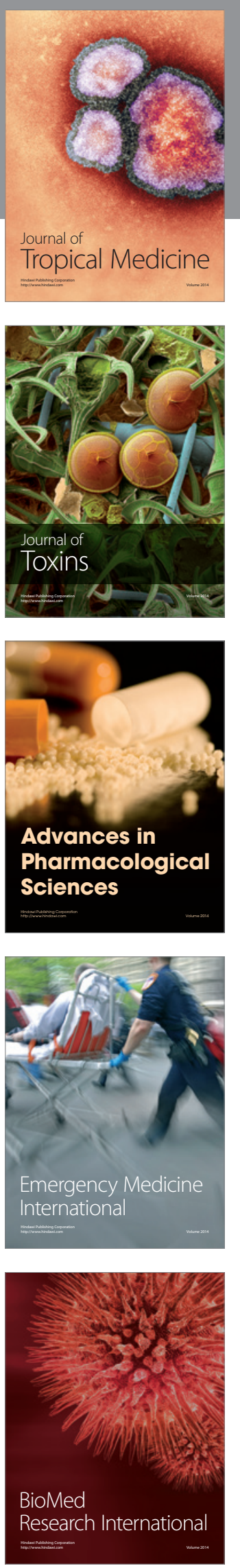
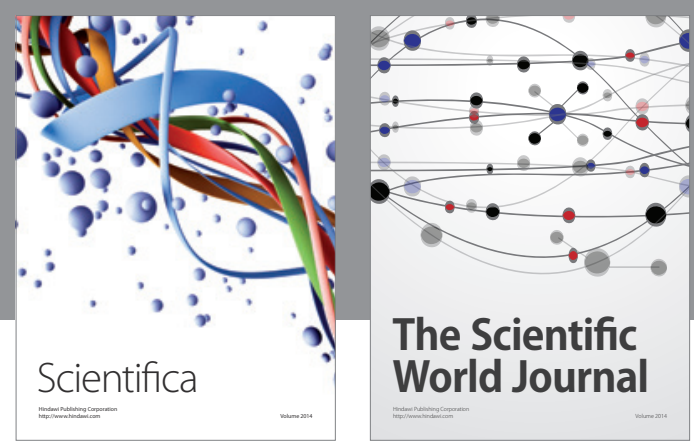

The Scientific World Journal
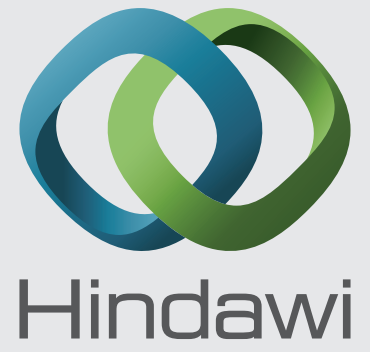

Submit your manuscripts at

http://www.hindawi.com
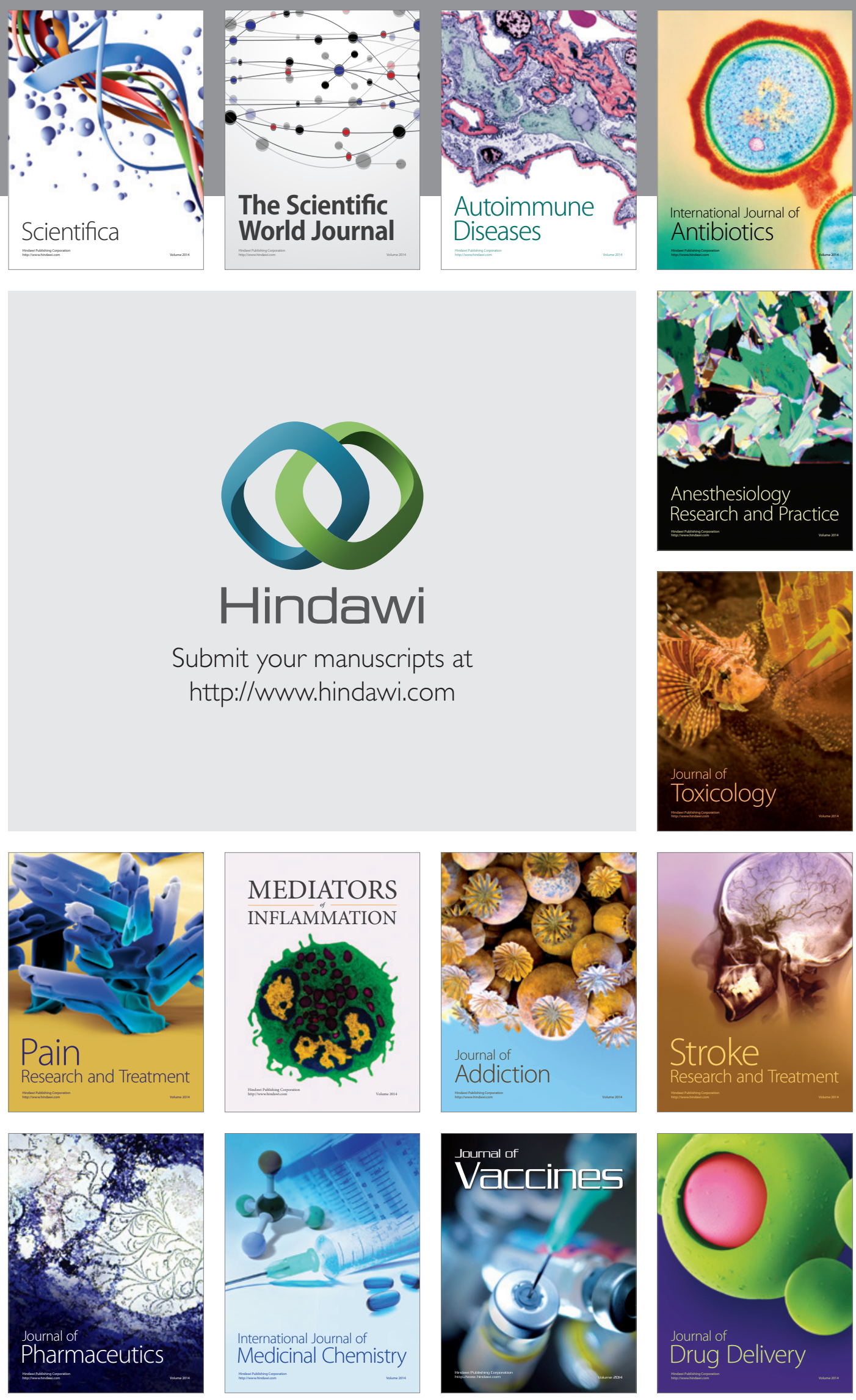